\title{
Perkembangan Terkini Membran Guided Tissue Regeneration/Guided Bone Regeneration sebagai Terapi Regenerasi Jaringan Periodontal
}

\author{
Cindy Cahaya* dan Sri Lelyati C Masulili** \\ *Program Pendidikan Dokter Gigi Spesialis Periodonsia, Fakultas Kedokteran Gigi, Universitas Indonesia, Jakarta, Indonesia \\ **Departemen Periodonsia, Fakultas Kedokteran Gigi, Universitas Indonesia, Jakarta, Indonesia \\ *JI Salemba Raya No.4 Jakarta Pusat, Indonesia; e-mail: Cindy_hezkil@yahoo.co.id
}

\begin{abstract}
ABSTRAK
Periodontitis adalah salah satu penyakit patologis yang mempengaruhi integritas sistem periodontal yang menyebabkan kerusakan jaringan periodontal yang berlanjut pada kehilangan gigi. Beberapa tahun belakangan ini banyak ketertarikan untuk melakukan usaha regenerasi jaringan periodontal, tidak saja untuk menghentikan proses perjalanan penyakit namun juga mengembalikan jaringan periodontal yang telah hilang. Sasaran dari terapi regeneratif periodontal adalah menggantikan tulang, sementum dan ligamentum periodontal pada permukaan gigi yang terkena penyakit. Prosedur regenerasi antara lain berupa soft tissue graft, bone graft, biomodifikasi akar gigi, guided tissue regeneration serta kombinasi prosedur-prosedur di atas, termasuk prosedur bedah restoratif yang berhubungan dengan rehabilitasi oral dengan penempatan dental implan. Pada tingkat selular, regenerasi periodontal adalah proses kompleks yang membutuhkan proliferasi yang terorganisasi, differensiasi dan pengembangan berbagai tipe sel untuk membentuk perlekatan periodontal. Rasionalisasi penggunaan guided tissue regeneration sebagai membran pembatas adalah menahan epitel dan gingiva jaringan pendukung, sebagai barrier membrane mempertahankan ruang dan gigi serta menstabilkan bekuan darah. Pada makalah ini akan dibahas sekilas mengenai 1 . Proses penyembuhan terapi periodontal meliputi regenerasi, repair ataupun pembentukan perlekatan baru. 2. Periodontal spesific tissue engineering. 3. Berbagai jenis membran/guided tissue regeneration yang beredar di pasaran dengan keuntungan dan kerugian sekaligus karakteristik masing-masing membran. 4. Perkembangan membran terbaru sebagai terapi regenerasi penyakit periodontal. Tujuan penulisan untuk memberi gambaran masa depan mengenai terapi regenerasi yang menjanjikan sebagai perkembangan terapi penyakit periodontal.
\end{abstract}

Maj Ked Gi Ind. Juni 2015; 1(1): hal 1-11

Kata kunci: membran, regenerasi, repair dan perlekatan baru

ABSTRACT: Latest Development of Guided Tissue Regeneration and Guided Bone Regeneration Membrane as Regenerative Therapy on Periodontal Tissue. Periodontitis is a patological state which influences the integrity of periodontal system that could lead to the destruction of the periodontal tissue and end up with tooth loss. Currently, there are so many researches and efforts to regenerate periodontal tissue, not only to stop the process of the disease but also to reconstruct the periodontal tissue. Periodontal regenerative therapy aims at directing the growth of new bone, cementum and periodontal ligament on the affected teeth. Regenerative procedures consist of soft tissue graft, bone graft, roots biomodification, guided tissue regeneration and combination of the procedures, including restorative surgical procedure that is connected with oral rehabilitation with implant placement. At cellular phase, periodontal regeneration is a complex process with well-organized proliferation, distinction, and development of various type of cell to form attachment of periodontal tissue. Rationalization of the use of guided tissue regeneration as barrier membrane is to prohibit the penetration of epithelial and connective tissue migration into the defect, to maintain space, and to stabilize the clot. This research discusses: 1. Healing process on periodontal therapy including regeneration, repair or formation of new attachment. 2. Periodontal specific tissue engineering. 3. Various commercially available membrane/guided tissue regeneration in the market with its advantages and disadvantages and their characteristics. 4. Recent advancement of membrane as regenerative therapy on periodontal disease. In addition, this review is presented to give an outlook for promising regenerative therapy as a part of developing knowledge and skills to treat periodontal disease.

Maj Ked Gi Ind. Juni 2015; 1(1): hal 1-11

Keywords: membrane, regeneration, repair and new attachment

\section{PENDAHULUAN}

National Institute of Dental and Craniofacial Research (NIDCR, National Institutes of Health, United States, menerangkan terdapat hampir
$90 \%$ dari populasi dewasa berusia lebih dari 70 tahun mengalami penyakit yang berkaitan dengan periodontal. ${ }^{1,2}$ Pada tingkat selular, regenerasi periodontal adalah proses kompleks 
yang membutuhkan proliferasi yang terorganisasi, differensiasi dan pengembangan berbagai tipe sel untuk membentuk perlekatan periodontal.

Teknik Guided Tissue Regeneration (GTR) dimulai oleh Nyman dkk pada tahun 1982. Istilah GTR digunakan oleh Gottlow pada tahun 1986, yang perlahan menjadi dapat diterima sebagai terapi regeneratif. World Workshop in Periodontic pada tahun 1996 mendefinisikan GTR sebagai "Prosedur percobaan untuk meregenerasi struktur periodontal yang hilang melalui respon jaringan yang berbeda", dengan cara memberikan barriers (pembatas) untuk menahan epitel dan korium gingiva dari permukaan akar. Barrier membran juga berguna untuk mencapai primary intention penyembuhan luka, mengisolasi defek dari gingival dan menstabilkan clot (bekuan darah). ${ }^{3}$

Selama dekade terakhir, berbagai tindakan bedah regeneratif telah diusulkan dan diteliti untuk regenerasi jaringan periodontal spesifik seperti tulang alveolar, sementum, ligamen periodontal dan gingiva. ${ }^{2}$ Perawatan-perawatan ini meliputi pemanfaatan berbagai pendekatan bedah, membran, satu seri bone graft serta berbagai material osteokonduktif/induktif atau gabungan protein, exogenous growth factors, cell-based technology dan gen dari recombinant technology. Pendekatan regenerasi jaringan periodontal mencapai sukses diikuti dengan strategi penggunaan GTR/GBR (Guided bone regeneration), meski hasil yang didapat bervariasi tergantung dari umur pasien, besar defek, genetik dan efek demografik serta gaya hidup. ${ }^{4,5}$

Pada awal tahun 1990an, Langer dan Vacanti mengusulkan tissue engineering untuk meregenerasi jaringan yang rusak dan merestorasi berbagai fungsi dari jaringan dan organ manusia yang rusak. ${ }^{6}$ Prinsip tissue engineering untuk regenerasi melibatkan kombinasi tiga elemen utama, seperti rangka (scaffolds) atau membran, regeneratif sel atau stem cells, dan cell signaling molecules atau growth factors. ${ }^{2}$

Kemajuan dalam ilmu pengetahuan dan teknologi dari nanomaterial mengarah pada pendekatan secara elektrospinning (e-spinning) ${ }^{7,8}$ dari biomimetik multifungsional growth-enhancing regenerative membrane untuk periodontal tissue engineering. Electrospun nanofibrous scaffolds/ membran lebih mirip dalam skala dan morfologi ekstraselular matrik protein (fibers) dengan diameter berkisar dari $50-500 \mathrm{~nm}^{9}$

Pendekatan perawatan yang berbeda diusulkan untuk meregenerasi jaringan periodontal yang rusak dalam kasus resesi gingiva dan periodontitis. Untuk merawat kasus resesi gingiva, prosedur bedah tradisional menggunakan jaringan transplantasi autogenus (misal diambil di area palatal). Tissue-derived collagen-based membrane telah dapat menggantikan prosedur tersebut, sehingga dapat menghindari pembedahan berulang, mengurangi nyeri dan ketidaknyamanan pada pasien. ${ }^{10}$ Strategi untuk menggunakan baik membran sintetik maupun tissue-derived membran sebagai barriers, dengan atau tanpa kalsium fosfat based bone graft telah mendapatkan perhatian yang besar untuk merestorasi fungsi dari jaringan periodontal yang rusak atau memiliki efek patologis. .11, $^{12}$

\section{Penyembuhan Pasca Terapi Periodontal}

Proses penyembuhan setelah terapi periodontal, walaupun terdiri atas berbagai macam terapi, pada dasarnya adalah sama. Proses ini terdiri dari pembuangan terhadap debris dari jaringan yang mengalami degenerasi dan pergantian jaringan yang hancur akibat penyakit.

\subsection{Regenerasi}

Regenerasi adalah proses pertumbuhan struktur jaringan yang baru melalui pertumbuhan serta differensiasi dari sel baru dan substansi interseluler. Regenerasi akan menghasilkan tipe jaringan yang sama dengan jaringan sebelumnya yang telah rusak. Pada jaringan periodontal, epitel pada gingiva digantikan oleh epitel, sedangkan jaringan ikat dan ligamen periodontal digantikan oleh jaringan ikat yang merupakan prekursor terhadap keduanya. Sel jaringan ikat yang belum berdifferensi akan berkembang menjadi osteoblas dan sementoblas, yang kemudian akan membentuk tulang dan sementum. ${ }^{13}$ Penyembuhan regenerasi ini yang diharapkan terbentuk setelah terapi periodontal, karena 
secara histologis jaringan yang terbentuk adalah jaringan yang fungsional.

Regenerasi pada jaringan periodontal merupakan proses fisiologis yang berjalan terus menerus. Pada kondisi yang normal, sel baru dan jaringan secara konstan terbentuk untuk menggantikan sel dan jaringan yang telah mati, ini yang disebut dengan terminologi wear and tear repair. Hal tersebut terjadi melalui proses aktivitas mitotik pada epitel gingiva dan jaringan ikat dari ligamen periodontal; pembentukan tulang baru; dan deposisi sementum yang terus menerus terjadi. Regenerasi juga terjadi selama proses destruktif akibat penyakit periodontal. Penyakit gingival dan periodontal merupakan proses inflamasi kronis, demikian juga lesi penyembuhan yang terjadi. atau membran yang merupakan biomaterial atau matriks berperan sebagai kerangka untuk membentuk struktur guna memfasilitasi proses regenerasi jaringan. Regenerasi sel atau stem sel, yang merupakan precursor sel. Komplikasi utama dan faktor yang membatasi regenerasi jaringan periodontal adalah mikroba patogen yang melekat pada permukaan gigi dan mengkontaminasi jejas periodontal. Kontrol infeksi harus dilakukan agar proses regenerasi optimal. ${ }^{14}$

\subsection{Repair}

Proses repair memperbaiki kontinuitas dari margin gingiva yang terkena penyakit dan menciptakan kembali sulkus gingiva yang normal di tingkat yang sama seperti dasar poket periodontal

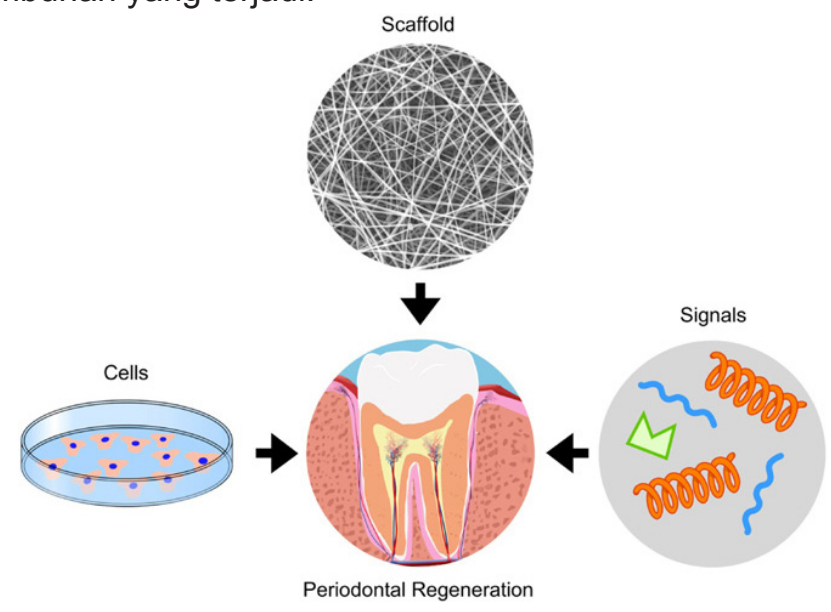

Gambar 1.1 Gambar skematik dari tiga komponen utama yang terlibat dalam craniofacial tissue engineering. (1) signaling molecules (missal BMPs dan FGFs), (2) progenitor/stem sel (missal dental pulpa stem sel) dan (3) estraselular matrik yang menyerupai rangka (scaffolds) (misalnya polimer alami atau sintetik. ${ }^{10}$

Menurut Langer dan Vacanti, ${ }^{6}$ regenerasi jaringan periodontal yang terlibat dalam konsep tissue engineering memiliki tiga komponen utama yaitu sinyal molekul yang sesuai, regenerasi sel, dan scaffold (Gambar 1.1). Sinyal molekul (salah satunya berupa faktor pertumbuhan/growth factor) berperan untuk memodulasi aktivitas seluler serta merangsang sel-sel untuk berdiferensiasi dan memproduksi matrik untuk perkembangan jaringan. Vaskularisasi jaringan yang baru membentuk sinyal angiogenik sebagai pensuplai nutrisi untuk pertumbuhan jaringan serta mempertahankan keadaan homeostasis dalam jaringan. Scaffold pada permukaan akar. Proses ini disebut penyembuhan dengan jaringan parut, terjadi penghentian proses kerusakan tulang namun perlekatan gingiva dan ketinggian tulang tidak dapat diperoleh kembali. ${ }^{15}$ Perlekatan gingiva pada permukaan akar dapat diperoleh kembali (baik sebagian maupun seluruhnya) melalui penggunaan material dan teknik khusus pada terapi. Apabila hal tersebut tidak dilakukan atau jika tindakan yang dilakukan gagal maka jaringan hanya mengalami proses repair. ${ }^{15}$ Secara histologis penyembuhan dengan repair membentuk long junctional epithelium, adesi jaringan ikat baru, dan ankilosis. ${ }^{16}$ 


\subsection{New Attachment / Perlekatan Baru}

New attachment adalah bagian yang melekatkan serat ligamen periodontal yang baru ke permukaan sementum baru, serta perlekatan epitel gingiva ke permukaan gigi yang sebelumnya hilang karena penyakit periodontal. Perlekatan pada gingiva atau ligamen periodontal pada permukaan gigi yang telah hilang karena perawatan akan menciptakan proses penyembuhan atau perlekatan kembali (reattachment) jaringan periodontal namun tidak terjadi new attachment. ${ }^{15}$

\section{Periodontal Spesifik Tissue Engineering}

Strategi yang berbeda dalam terapi periodontal bertujuan untuk: mereduksi/mengeliminasi jaringan yang mengalami inflamasi yang disebabkan oleh plak bakteri, mengkoreksi defek atau masalah anatomis berkaitan dengan penyakit periodontal, meregenerasi jaringan periodontal yang baru. ${ }^{3,17}$ Perkembangan sementum yang baru dengan serat-serat ligamen periodontal yang berhubungan dengan tulang alveolar adalah tujuan utama dari regenerasi periodontal. ${ }^{8,11,17}$ Dua teknik bedah telah banyak digunakan untuk memperbaiki, meregenerasi berbagai jaringan periodontal yang berbeda, yaitu GTR dan GBR.

Aplikasi pertama penggunaan membrane terbukti menunjukkan keberhasilan GTR meningkatkan regenerasi jaringan periodontal manusia yaitu selulose asetat oleh Milipore. Sejak itu, banyak membran baru didisain untuk keperluan klinis dengan segala kekurangan dan kelebihan masingmasing. Barrier membran harus memenuhi syarat dasar, diantaranya: 1. Biokompatibilitas; interaksi antara membran dan jaringan inang seharusnya tidak menginduksi efek yang buruk; 2 . Space making: kemampuan untuk mempertahankan ruangan untuk sel dari jaringan tulang sekitar yang bermigrasi untukdurasi waktu yang stabil; 3. Cell-occlusiveness: mencegah jaringan fibrosa menghambat pembentukan tulang dari invasi sisi defek; 4. Mechanical strength: sifat-sifat fisik yang layak untuk membiarkan dan melindungi proses penyembuhan, termasuk proteksi blood clot di bawahnya; dan 5. Degradability: waktu degrasi yang tepat waktu berkenaan dengan rerata regenerasi dari jaringan tulang untuk menghindari prosedur bedah yang kedua untuk mengangkat membran. ${ }^{18}$

Indikasi untuk prosedur $G T R^{23}$ adalah bentuk kerusakan yang sempit, defek dua atau tiga dinding infraboni, defek circumferential, klas II defek furkasi, defek resesi. Kontraindikasi untuk prosedur GTR: Kondisi sistemik yang menjadi kontraindikasi bedah, infeksi pada defek, oral higiene yang buruk, perokok berat, kegoyangan gigi lebih dari $1 \mathrm{~mm}$, defek kurang dari $4 \mathrm{~mm}$ dalamnya, lebar perlekatan gigiva pada sisi defek kurang atau sama dengan $1 \mathrm{~mm}$, ketebalan attached gingiva pada sisi defek kurang atau sama dengan 0,5 , furkasi dengan short root trunks, secara umum terjadi kehilangan tulang horizontal, terdapat lesi lanjut dengan dukungan jaringan yang lemah, dan defek multiple. ${ }^{19}$

\subsection{Membran Barrier untuk Aplikasi GTR dan GBR}

Strategi mengisolasi defek periodontal dengan "mat-like material" adalah fungsinya sebagai barrier fisik untuk menghindari sel gingival menginvasi yang membawa pada perkembangan membran GTR/GBR. ${ }^{20}$ Membran GTR/GBR dibagi dalam dua kelompok, resorbable dan non-resorbable, tergantung karakteristik degradasinya.

\subsubsection{Membran Non-resorbable}

'Gold standard' membran non-resorbable pada prosedur GTR/GBR adalah: 1. Expanded Highdensity polytetrafluoroethylene, PTFE (misalnya Cytoplast, TXT-200, Osteogenics Biomedical, Lubbock, TX, USA); 2. Titanium-reinforced highdensity polytetrafluroethylene (misalnya Cythoplast Ti-250, Osteogenics Biomedical, Lubbock, TX, USA);21 3. Titanium-mesh (Ti-mesh). ${ }^{22}$ Membran PTFE bersifat inert dan biocompatible, bertindak sebagi barrier selular, menyediakan ruang untuk regenerasi jaringan, serta mengijinkan integrasi jaringan. Studi menunjukkan bahwa membran titanium reinforcement of high-density PTFE menuntun pada kapasitas regenerasi superior dibandingkan dengan traditional expanded PTFE yang disebabkan dukungan mekanikal yang diberikan oleh frame titanium terhadap gaya kompresif oleh jaringan lunak di atasnya. ${ }^{23}$ 
Titanium Mesh, titanium-reinforced barrier membran diperkenalkan sebagai pilihan untuk $G B R$, karena menyediakan dukungan mekanik yang lebih baik sehingga menyediakan ruangan yang lebih besar untuk tulang dan jaringan tumbuh kembali. Menurut Rakhmantia dkk. ${ }^{22}$ terdapat empat keuntungan dari Timeshmembran sebagaialternatifmembran PTFE, yaitu menyediakan ruangan yang luas, mempertahankan dan mencegah kolapsnya kontur, mencegah kompresi mukosa, mencegah displacement graft, plasticity mengijinkan pelengkungan dan adaptasi terhadap defek tulang yang unik.

Kerugian utama dari membran Ti-Mesh adalah peningkatan paparan karena kekakuannya dan juga lebih kompleks pada pembedahan kedua untuk mengeluarkannya. ${ }^{22} \mathrm{Hal}$ ini jugalah yang menjadi kerugian dari non-resorbable membrane, sehingga dibutuhkan pembedahan tambahan untuk mengambil membran, dengan berimplikasi tidak hanya terdapat nyeri tambahan tetapi juga ketidaknyamanan dan beban ekonomi pada pasien. Untuk mengeliminasi prosedur bedah kedua, dikembangkan membran yang dapat diresorbsi. ${ }^{17,24}$

\subsubsection{Membran Resorbable}

Mayoritas membran sintetis polimer yang dapat diresorbsi untuk regenerasi periodontal yang beredar di pasaran berbahan dasar poliester atau tissue-derived collagens. Membran yang berbahan dasar polyester misalnya poly (glycolic acid) (PGA), poly (lactic acid) (PLA), poly (e-caprolactone) $(P C L)$ dan polimer-polimernya. Sifat-sifat membran poliester: biokompatibel (dapat diterima tubuh) biodegradable (dapat didegradasi tubuh), mudah dalam penanganan secara klinis dibandingkan membran PTFE dan mengijinkan terjadinya tissue integration. Rata-rata kecepatan resorbsi menjadi penting, setidaknya 4-6 minggu waktu yang dibutuhkan untuk berhasil terjadinya regenerasi dari sistem periodontal. ${ }^{17}$

Pada umumnya biodegradasi dari poliesterpoliester ini melibatkan proses perpecahan nonenzimatik dari PGA dan PLA menjadi piruvat dan asam laktat, yang merupakan produk akhir dari pencernaan karbohidrat. Milella dkk., mengevaluasi karakteristik morfologi dan mekanik dari membran berbahan dasar poliester yang beredar di pasaran
(Resolut ${ }^{\circledR}$ LT dan Biofix $\circledast$ ). Walaupun membranmembran ini menunjukkan kekuatan inisial yang tinggi ( 12-14 MPa), membran-membran ini hampir kehilangan sifat-sifat struktur dan mekaniknya dalam empat minggu setelah inkubasi dalam medium kultur. Kekuatan maksimum setelah 14 hari terpapar akan menurun secara signifikan (di bawah $1 \mathrm{MPa}$ ). ${ }^{25}$

Dari studi terbaru yang dilakukan Li dkk., ${ }^{26}$ membran yang diproses dengan berbahan dasar nano-hydroxyapatite/polyamide-66 dengan gradient porosity dan diusulkan bahwa penambahan $\mathrm{n}$-Hap akan menjamin membran dengan tensile strength (2-3 MPa). Sebagai tambahan lain dilaporkan bahwa terdapat respon sel yang lemah sehingga membatasi penggunaan/aplikasi GTR/GRB ini.

Kerugian utama dari membran yang dapat diresorbsi ini adalah tidak dapatnya diprediksi waktu resorpsi serta derajat degradasinya, yang berpengaruh langsung pada pembentukan tulang. ${ }^{27}$ Membran yang ideal harus dapat didegradasi atau diresorpsi dengan kecepatan yang sama dengan terjadinya pembentukan tulang.

\subsubsection{Membran Berbahan Dasar Material Natural}

(Biodegradable Resorbable Membrane from Natural Material)

Membran berbahan dasar material natural biasanya berasal dari kulit manusia, tendon achiles sapi, kulit babi, dengan afinitas dan biokompatibilitas yang sangat baik. Kolagen adalah unsur pokok dari ekstraseluar matrik alami (ECM). Membran dengan bahan dasar tissue-derived collagen dari kulit manusia (Alloderm ${ }^{\circledR}$, Lifecell, Branchburg, NJ, USA), tendon Achiller sapi (Cytoplast ${ }^{\circledR}$ RTM Collagen, City, State, USA) atau kulit babi (BioGide ${ }^{\circledR}$, Osteohealth, Shierly, NY, USA) adalah alternatif-alternatif penting dari sintetik polimer dalam prosedur GTR/GBR karena sel afinitas dan biokompatibilitasnya yang sangat baik. ${ }^{28,29}$

Kolagen tipe-1 memiliki keterbatasan dalam penggunaannya karena biaya yang tinggi dan definisi sumber komersialnya, sehingga sulit untuk mengkontrol sifat-sifat degradasi dan mekanikalnya. AlloDerm ${ }^{\circledR}$ adalah aselular freeze-dried dermal matrix graft dengan komposisi utamanya adalah kolagen tipe-1 yang diambil dari kulit manusia 
(kadafer). ${ }^{29,30}$ Menurut pabriknya, pemrosesan tidak menyebabkan kerusakan pada struktur biokemikal penting yang menunjukkan kebutuhan untuk mempertahankan sifat regenerasi jaringan secara alami dan meninggalkan kolagen ekstraselular matrik sebagai dasar pendukung untuk struktur jaringan dan menuntun fungsi-fungsi selular. ${ }^{31}$
Collagen-based membrane menunjukkan performa yang sangat lemah secara in vivo sebagai membran yang dimulai dari degradasi. ${ }^{24}$ Sebagai tambahan, terdapat resiko transmisi penyakit karena penggunaan kolagen dari manusia atau hewan memiliki pengaturan atau keterbatasan lain, seperti kepercayaan religi pada

Tabel 1. Klasifikasi Berbagai Jenis Membran di Pasaran 22

\begin{tabular}{|c|c|c|c|c|c|c|c|}
\hline \multicolumn{2}{|c|}{ Membranes } & $\begin{array}{l}\text { Commercial } \\
\text { name }\end{array}$ & $\begin{array}{l}\text { Manufacturer } \\
\text { and nation }\end{array}$ & Material & Properties & Comments & Reference \\
\hline \multirow{13}{*}{$\begin{array}{l}\text { Non- } \\
\text { resorbable } \\
\text { membranes }\end{array}$} & \multirow[b]{2}{*}{ e-PTFE } & Gore-Tex & $\begin{array}{l}\text { W. L. Gore \& } \\
\text { Associates, } \\
\text { Inc., USA }\end{array}$ & e-PTFE & $\begin{array}{l}\text { Good space } \\
\text { maintainer } \\
\text { Easy to handle }\end{array}$ & $\begin{array}{l}\text { Longest clinical } \\
\text { experience }\end{array}$ & 23.24 \\
\hline & & Gore-Tex-TI & $\begin{array}{l}\text { W. L. Gore \& } \\
\text { Associates, } \\
\text { Inc., USA }\end{array}$ & Ti-e-PTFE & $\begin{array}{l}\text { Most stable space } \\
\text { maintainer } \\
\text { Filler material } \\
\text { unnecessary }\end{array}$ & $\begin{array}{c}\text { Titanium should } \\
\text { not be exposed } \\
\text { Commonly used } \\
\text { in ridge } \\
\text { augmentation }\end{array}$ & o \\
\hline & \multirow{4}{*}{ d-PTFE } & $\begin{array}{l}\text { High-density } \\
\text { Gore-Tex }\end{array}$ & $\begin{array}{l}\text { W. L. Gore \& } \\
\text { Associates, } \\
\text { Inc., USA }\end{array}$ & \multirow{4}{*}{ d-PTFE } & $0.2 \mu \mathrm{m}$ pores & $\begin{array}{l}\text { Avoid a second- } \\
\text { ary surgery }\end{array}$ & $x$ \\
\hline & & Cytoplast & $\begin{array}{c}\text { Osteogenics } \\
\text { Biomedical., } \\
\text { USA }\end{array}$ & & $<0.3 \mu \mathrm{m}$ pores & $\begin{array}{l}\text { Primary closure } \\
\text { unnecessary }\end{array}$ & 2 \\
\hline & & TefGen FD & $\begin{array}{l}\text { Lifecore Bio- } \\
\text { medical, Inc., } \\
\text { USA }\end{array}$ & & $0.2-0.3 \mu \mathrm{m}$ pores & Easy to detach & $a$ \\
\hline & & $\begin{array}{l}\text { Non-resorba- } \\
\text { ble ACE }\end{array}$ & $\begin{array}{l}\text { Surgical supply, } \\
\text { Inc., USA }\end{array}$ & & $\begin{array}{l}<0.2 \mu \mathrm{m} \text { pores } \\
0.2 \mathrm{~mm} \text { thick }\end{array}$ & $\begin{array}{l}\text { Limited cell } \\
\text { proliferation }\end{array}$ & 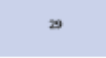 \\
\hline & \multirow{7}{*}{$\begin{array}{l}\text { Tita- } \\
\text { nium } \\
\text { mesh }\end{array}$} & $\begin{array}{l}\text { Ti-Micromesh } \\
\text { ACE }\end{array}$ & $\begin{array}{l}\text { Surgical supply, } \\
\text { Inc., USA }\end{array}$ & \multirow[b]{5}{*}{$\begin{array}{l}\text { Poly-DL- } \\
\text { lactic acid }\end{array}$} & $\begin{array}{l}1,700 \mathrm{~mm} \text { pores } \\
0.1 \mathrm{~mm} \text { thick }\end{array}$ & $\begin{array}{l}\text { Ideal long term } \\
\text { survival rate }\end{array}$ & 90 \\
\hline & & $\begin{array}{l}\text { Tocksystem } \\
\text { Mesh }\end{array}$ & $\begin{array}{l}\text { Tocksystem, } \\
\text { Italy }\end{array}$ & & $\begin{array}{c}0.1-6.5 \mathrm{~mm} \text { pore } \\
0.1 \mathrm{~mm} \text { thick }\end{array}$ & $\begin{array}{l}\text { Minimal } \\
\text { resorption and } \\
\text { inflammation }\end{array}$ & s1 \\
\hline & & $\begin{array}{c}\text { Frios } \\
\text { BoneShields }\end{array}$ & $\begin{array}{l}\text { Dentsply Fria- } \\
\text { dent, Germany }\end{array}$ & & $\begin{array}{l}0.03 \mathrm{~mm} \text { pores } \\
0.1 \mathrm{~mm} \text { thick }\end{array}$ & $\begin{array}{l}\text { Sufficient bone } \\
\text { to regenerate }\end{array}$ & st \\
\hline & & M-TAM & & & $\begin{array}{l}1,700 \mathrm{~mm} \text { pores } \\
0.1-0.3 \mathrm{~mm} \text { thick }\end{array}$ & $\begin{array}{l}\text { Excellent tissue } \\
\text { compatibility }\end{array}$ & 32 \\
\hline & & EpiGuide & $\begin{array}{l}\text { Kensey Nash } \\
\text { corporation, } \\
\text { USA }\end{array}$ & & $\begin{array}{l}\text { Three-layer mem- } \\
\text { brane } \\
\text { Resorption: 6-12 } \\
\text { weeks }\end{array}$ & $\begin{array}{l}\text { Self-supporting } \\
\text { Support devel- } \\
\text { oped blood clot }\end{array}$ & $s$ \\
\hline & & Resolut & $\begin{array}{l}\text { W. L. Gore \& } \\
\text { Associates, } \\
\text { Inc., USA }\end{array}$ & $\begin{array}{l}\text { Poly-DL- } \\
\text { lactid/ } \\
\text { Co-glycolid }\end{array}$ & $\begin{array}{c}\text { Resorption: } 10 \\
\text { weeks } \\
\text { Good space } \\
\text { maintainer }\end{array}$ & $\begin{array}{c}\text { Good tissue } \\
\text { integration } \\
\text { Separate suture } \\
\text { material }\end{array}$ & $s$ \\
\hline & & Vivosorb & $\begin{array}{c}\text { Polyganics B.V. } \\
\text { NL }\end{array}$ & $\begin{array}{l}\text { DL-lactide-E- } \\
\text { caprolactone } \\
\text { (PLCL) }\end{array}$ & $\begin{array}{l}\text { Anti-adhesive } \\
\text { barrier } \\
\text { Up to } 8 \text { weeks' } \\
\text { mechanical prop- } \\
\text { erties }\end{array}$ & $\begin{array}{l}\text { Act as a nerve } \\
\text { guide }\end{array}$ & m \\
\hline \multirow{7}{*}{$\begin{array}{l}\text { Natural biode } \\
\text { material }\end{array}$} & \multirow{7}{*}{ gradable } & $\begin{array}{l}\text { Plasma rich } \\
\text { in growth } \\
\text { factors(PRGF- } \\
\text { Endoret) }\end{array}$ & $\begin{array}{c}\text { BTI } \\
\text { Biotechnology } \\
\text { Institute, } \\
\text { Vitoria, Spain }\end{array}$ & $\begin{array}{l}\text { Patients' } \\
\text { own blood }\end{array}$ & $\begin{array}{l}\text { Abundant growth } \\
\text { factors and pro- } \\
\text { teins mediate cell } \\
\text { behaviors } \\
\text { Different formula- } \\
\text { tions for various } \\
\text { usages } \\
\text { Total resorption }\end{array}$ & $\begin{array}{c}\text { Enhance osse- } \\
\text { ointegration and } \\
\text { initial implant } \\
\text { stability } \\
\text { Promote new } \\
\text { bone formation } \\
\text { Encourage soft } \\
\text { tissue recovery }\end{array}$ & * \\
\hline & & Bio-Gide & $\begin{array}{l}\text { Osteohealth } \\
\text { Company, SUI }\end{array}$ & $\begin{array}{l}\text { Porcine I } \\
\text { and III }\end{array}$ & $\begin{array}{c}\text { Resorption: } 24 \\
\text { weeks } \\
\text { Mechanical } \\
\text { strength: } 7.5 \mathrm{MPa}\end{array}$ & $\begin{array}{l}\text { Usually used } \\
\text { in combina- } \\
\text { tion with filler } \\
\text { materials }\end{array}$ & 42 \\
\hline & & Bio-mend & Zimmer, USA & Bovine I & $\begin{array}{c}\text { Resorption: } 8 \\
\text { weeks } \\
\text { Mechanical } \\
\text { strength: } 3.5-22.5 \\
\text { MPa }\end{array}$ & $\begin{array}{c}\text { Fibrous network } \\
\text { Modulate cell } \\
\text { activities }\end{array}$ & 42 \\
\hline & & $\begin{array}{l}\text { Biosorb } \\
\text { membrane }\end{array}$ & 3M ESPE, USA & Bovine I & $\begin{array}{c}\text { Resorption: } 26-38 \\
\text { weeks }\end{array}$ & $\begin{array}{c}\text { Tissue } \\
\text { integration }\end{array}$ & 4 \\
\hline & & Neomem & Citagenix, CAN & Bovine I & $\begin{array}{c}\text { Double-layer } \\
\text { product } \\
\text { Resorption: 26-38 } \\
\text { weeks }\end{array}$ & $\begin{array}{l}\text { Used in severe } \\
\text { cases }\end{array}$ & 4h \\
\hline & & OsseoGuard & $\begin{array}{l}\text { BIOMET 3i, } \\
\text { USA }\end{array}$ & Bovine I & $\begin{array}{c}\text { Resorption: } 24-32 \\
\text { weeks }\end{array}$ & $\begin{array}{l}\text { Improve the } \\
\text { aesthetics of the } \\
\text { final prosthetics }\end{array}$ & as \\
\hline & & Ossix & $\begin{array}{l}\text { OraPharma, } \\
\text { Inc., USA }\end{array}$ & Porcine I & $\begin{array}{c}\text { Resorption: 16-24 } \\
\text { weeks }\end{array}$ & $\begin{array}{l}\text { Increase the } \\
\text { woven bone }\end{array}$ & * \\
\hline
\end{tabular}


penggunaannya. Sifat biomekanikal dan stabilitas matriks kolagen dapat ditingkatkan dengan proses potong silang fisikal/kemikal menggunakan radiasi ultraviolet (UV), genipin (Gp), glutaraldehyde, 1-ethyl -3-(3-dimetylaminopropyl) carbodi-imide hydrochloride (EDC). Dilaporkan bahwa agen seperti Genipin tidak hanya meningkatkan stabilitas collagen-based tissues secara signifikan, tetapi juga mengurangi efek antigennya. Pembentukan ikatan tambahan secara inter atau intramolekur dalam serat-serat kolagen meningkatkan sifat mekanikal dari jaringan biologi. ${ }^{29}$ Bottino dkk., menginvestigasi bagaimana agen Genipin (Gp) pada AlloDerm ${ }^{\circledR}$, protokal rehidrasi mempengaruhi sifat mekanik dan stabilitas collagen matrix. ${ }^{29}$

Kerugian dari PTFE-based non-resorbable (seperti diperlukan bedah yang kedua kali) dan resorbable membrane terutama dengan bahan dasar kolagen (seperti sifat-sifat mekanikal yang kurang memadai, juga sifat degradasi yang sulit diprediksi) telah memimpin pada studi untuk material membran. Beberapa kelompok penelitian telah menginvestigasi kemungkinan menggunakan membrane dengan berbagai tingkatan struktur yang secara fungsional dapat mempertahankan kecukupan sifat-sifat mekanikal selama penggunaan, kecepatan degradasi yang dapat diprediksi dan sifat-sifat bioaktif.,12 Pembentukan tulang akan distimulasi oleh kalsium fosfat berbahan dasar nanopartikel atau faktor-faktor pertumbuhan (seperti BMP-2, TGF- $\beta$ ) pada membran yang berhadapan pada jaringan keras, 3,12,32 dan kolonisasi bakteri akan dihambat dengan pemberian antibacterial agent pada membran yang berhadapan pada jaringan lunak. . $^{3,2,32}$

Pada tahun-tahun belakangan ini, banyak kelompok penelitian telah mencoba untuk mendisain dan mengembangkan GTR/GBR periodontal membran dengan fitur-fitur dan sifat-sifat yang diperlukan dengan mengkombinasikan polimer sintetis dan alami. Studi-studi ini mempersiapkan membran GTR/GBR menggunakan casting film, ${ }^{12}$ filtrasi dinamik dan e-spinning ${ }^{8}$ atau sintetik (PCL) dan atau alami kolagen, chitosan) polimer. Membran-membran ini telah dipersiapkan dengan atau tanpa obat terapi, faktor pertumbuhan ${ }^{33}$ dan atau partikel kalsium fosfat., ${ }^{8,11}$ Mayoritas dari metode-metode ini menghasilkan membran dengan potensial klinis yang sangat rendah karena densitas yang tinggi (sulit dalam penanganan) dan heterogen (kecepatan degradasi yang tidak sama). Teknik e-spinning telah menunjukkan potensial yang sangat besar untuk pemrosesan membran. ${ }^{8,34}$ E-spinning adalah teknik yang menjanjikan untuk mensintesis biomimic nanomatrik, termasuk membran untuk aplikasi GTR/GBR.

Li dkk., telah mengkultur sel-sel yang berbeda seperti fibroblast, sel kartilago dan mesenkhimal stem sel pada PLGA dan PCL nanofiber e-spun scaffolds dan menunjukkan kemampuan struktur nanofiber mendukung perlekatan sel dan proliferasi. ${ }^{35}$ Karena perlekatan daerah permukaan yang tinggi, kelompok fungsional permukaan poripori yang saling berhubungan dan nano-scale size, scaffolds dari nanofiber lebih baik daripada micro-fibers atau bentuk morfologi lain. Scaffolds nanofibrous akan: menstimulasi interaksi positif sel-ECM, meningkatkan kecepatan proliferasi, mempertahankan sel fenotip, mendukung differensiasi stem sel, mendukung secara in-vivo seperti 3D perlekatan matriks mengaktivasi jalur cell-signaling dengan cara menyediakan stimulasi fisik dan kimia pada sel. ${ }^{36}$

Proses e-spinning dari polimer-polimer yang berbeda, baik polimer sintetik sendirian maupun komibinasi dengan protein alami akan meningkatkan integritas mekanikal dan dimensi stabilitas dari mesh e-spun. ${ }^{37}$ Membran sintetik/ protein lapis demi lapis dapat dibangun dengan e-spinning dalam kombinasi dengan frezze-drying atau proses fase pemisahan.

Membran untuk GTR/GBR mampu memicu pertumbuhan tulang lebih cepat sekaligus menghalau infiltrasi jaringan epitel masuk ke defek termasuk sangat efektif dan unik untuk kolonisasi bakteri secara in vivo. Secara klinis, pemberian antibiotic secara oral sebagai terapi tambahan untuk penyakit periodontal membantu merduksi dan mengeliminasi keberadaan patogen pada cairan gingiva dan poket periodontal. ${ }^{38}$ 
Matriks tulang terdiri dari $65 \%$ mineral dan $25 \%$ protein. Fase mineral adalah kalsium fosfat di campur terutama oleh hidroksiapatit (Hap). Fase organik terdiri dari $90 \%$ kolagen tipe-1 dan sisa $10 \%$ terdiri dari berbagai proteoglikan dan protein lain. ${ }^{39}$ Bersama dengan osteokonduktif dan osteoinduktivity hidroksiapatit $\left(\mathrm{Ca}_{10}\left(\mathrm{PO}_{4}\right)_{6}(\mathrm{OH})_{2}\right)$ dikenal sebagai komponen kunci untuk konstruksi engineering jaringan tulang. ${ }^{40}$

Beberapa peneliti telah berhasil menggabungkan tetrasiklin hydrochlorid ( $\mathrm{TCH}$ ) dan metronidazol benzoat ke dalam larutan polimer yang berbeda dengan tujuan untuk mengembangkan material dengan sifat-sifat terapi. Chou dkk., ${ }^{41}$ melaporkan terdapat efek antibakteri pada dua jenis biodegradable membrane yang beredar di pasaran, yaitu membran berbahan dasar poliester-Resolut Adapt LT (Gote-Tex; W.L. Gote \& Associates, Inc., Flagstaff, AZ) dan tipe 1 kolagen dari sapi (bovine) -BioMend Extend (Zimmer Dental, Carlsbad, CA), setelah mineralisasi dengan zinc fosfat. Mineralisasi zinc fosfat sendiri menunjukkan penurunan aktivitas Actinobacillus actinomycetemcomitans secara signifikan dibandingkan dengan membran yang nonmineralized. ${ }^{41}$ Untuk studi terbaru, dikembangkan membrane GBR dengan bahan dasar silverhydrozyapatite-titania/polyamide nanocomposite (nAg-HA-TiO2/PA) dengan hasil aktivitas osteogenik yang lebih tinggi dibandingkan dengan e-PTFE, karena perbedaan tingkat alkaline-fosfatase. Terjadi penutupan defek secara keseluruhan baik untuk $n A g-H A-T i O 2 / P A$ dan e-PTFE setelah 8 minggu in vivo, menurut data radigrafik histomorfologi. ${ }^{42}$

Telah diketahui bahwa keberhasilan regenerasi periodontal tergantung pada interaksi antara material scaffold dan elemen kunci lain seperti faktor-faktor pertumbuhan, sel dan suplai darah. Faktor pertumbuhan seperti platelet rich plasmaPRP dan bone morphogenetic proteins-BMPs telah menunjukkan peningkatan penyembuhan periodontal dan regenerasi dengan memodulasi aktivitas selular dan menyediakan stimuli pada sel untuk berdifferensiasi dan sintesis ECM untuk mengembangkan jaringan baru.,42 Sementara itu penggunaan enamel matrik derivative secara klinis $(E M D, E m d o g a i n \AA$, Staumann AG, Basel,
Switzerland dan protein komponennya seperti amelogenin dan ameloblastin diperkirakan meningkatkan pembentukan perlekatan baru dengan terjadinya aselular/selular sementum baru dengan serat kolagen tertaut dan tulang alveolar baru. ${ }^{43}$ Menurut data terbaru, di luar dari kemampuan untuk menstimulasi angiogenesis, ${ }^{44}$ kegunaan EMD juga memainkan peran secara signifikan dalam ekspresi gen, produksi protein, proliferasi dan differensiasi osteoblas dan sel ligament periodontal. ${ }^{45}$

\subsection{Future Outlook}

Hydrogel menawarkan berbagai desain dan sintesis. ${ }^{46,47}$ Karena banyak sistem hydrogel telah diteliti untuk tissue engineering. Secara sinergis, kombinasi sifat-sifat hydrogel untuk masalah periodontal spesifik terutama keuntungan dalam aplikasi. Teknologi saat ini dan hasil dari literatur mengusulkan bahwa kombinasi dari graded e-spun nanomatrikx dan hydrogel memiliki potensi yang signifikan untuk digunakan dalam tissue engineering periodontal. Arah masa depan termasuk desain rasional untuk hydroge/yang dibutuhkan tidak hanya untuk mengkontrol degradasi dan sifat mekanik tetapi juga pertimbangan variabel biologis. Walau dalam hasil secara in vitro dengan e-spunscaffolds menunjukkan hasil akhir yang menjanjikan dengan menciptakan membran sintetik yang aktif secara biologi, masih terdapat keterbatasan secara signifikan berkaitan dengan scaffold ini.

\section{KESIMPULAN}

Terapi periodontal dengan GTR adalah terapi yang menjanjikan pada saat ini untuk menstimuli regenerasi jaringan periodontal yang rusak akibat penyakit periodontal. Karena membran/GTR ini menyediakan ruang untuk sel-sel berdifferensasi menjadi osteoblas dan sementoblas untuk membentuk tulang dan sementum yang baru, tanpa dihalangi oleh pertumbuhan epitel yang masuk ke dalam defek. Namun, ketersediaan membran yang berfungsi sebagai scaffold hanyalah satu dari tiga faktor lain yang diperlukan, yaitu diperlukan faktorfaktor pertumbuhan sebagai signaling molecule dan sel-sel progenitor/stem sel. 
Keberhasilan-keberhasilan penggunaan membran sebagai scaffold untuk meregenerasi jaringan periodontal, tidak lepas dari berbagai prasyarat yang harus dipersiapkan, dari pemilihan kasus, pemiliihan jenis membran yang sesuai dengan karakteristik, kelebihan dan kekurangan masingmasing membran, pemilihan jenis material bone graft, sekaligus keadaan sosial ekonomi termasuk keberatan-keberatan secara religious dari pasien yang dirawat. Masih dibutuhkan penelitian yang lebih lanjut untuk menemukan membran yang 'ideal' yang dapat meregenerasi jaringan periodontal.

\section{DAFTAR PUSTAKA}

1. Philstrom B, Michalowicz B, Johnson N. Periodontal Diseases. Lancet 2005; 366; 1809.

2. Nakashima M, Reddi A. The application of bone morphogenetic proteins to dental tissue engineering. Nat Biotechnol. 2003; 21: 1025.

3. Haney J, Nilveus R, McMillan P, Wikesjo $U$. Periodontal repair in dogs: expanded polytetrafluroethulene barrier support wound stabilization and enhance bone regeneration. J Periodontol. 1993; 64(9): 883-90.

4. Jung $R$, Clauser R, Scharer P, Hammerle C, Saeler H, Weber F. Effect or rhBMT-2 On guided bone regeneration in humans-a randomized, controlled clinical and histomorphometric study. Clin Oral Implants Res. 2003; 14: 556.

5. Trombelli L. which reconstructive procedures are effective for treating the periodontal intraosseous defect. Periodontol 2000. 2005; 37: 88 .

6. Langer $\mathrm{R}$, Vacanti J. Tissue engineering. Science (8).1993; 260: 920.

7. Agarwal S, Greiner A, Wendorff J. electrospinning of manmade and biopolymer nanofibers-progress in techniques, materials, and applications. Adv Funct Mater. 2009; 19: 2863.

8. Yang F, Both S, Yang X, Walboomers X, Jansen J. development of an electrospun nano-apatite/PCL composite membrane for GTR/GBR aplications. Acta Biomater. 2009; 5: 3295.
9. Bottino MC, Thomas V, Schmidt G, Vohra YK, Chu TG, Kowolik MJ, Janowski GM, Recent advances in the development of GTR/GBR membranes for periodontal regeneration - A materials perspective. Dent Mater [Internet]. The Academy of Dental Materials; 2012; 28(7): 703-21. Available from: http://dx.doi. org/10.1016/j.dental.2012.04.022

10. Bottino $M$, Jose $M$, Thomas $V$, Dean $D$, Janowski G. freeze-dried acellular dermal matrix graft: effects of rehydration on physical, chemical, and mechanical properties. Dent Mater. 2009; 25: 1109.

11. Kikuchi M, Koyama Y, Yamada T, Imamura Y, Okada T, Shirahama N. development of guided bone regeneration membrane composed of beta-tricalcium phosphate and poly (L-lactide-co-glycolide-epsilon-caprolactone) composites. Biomaterials. 2004; 25: 5979.

12. Liao S, Wang W, Uo M, Ohkawa S, Akasaka T, Tamura K. A Three layered nano-carbonated hydroxyapatite/collaen/PLGA composite membrane for guided tissue regeneration. Biomaterial. 2005; 23: 7564.

13. Carranza F, Takei H. Rationale for Periodontal Treatment. Caranza's Clinical Periodontology, 11th Ed. 2012.p. 387-90.

14. Taba Jr M, Jin Q, Sugai J GW. Current Concept in Periodontan Bioengineering. Orthod Craniofacial Res. 2005; 8: 292-302.

15. Newman, Takei, Klokkevold C. Carranza's Clinical Periodontology. 11'ed ed. St. Louis, Missouri: Elsevier; 2006. 387-390.

16. Kao R. Periodontal Regeneration and Reconstructive Surgery. In: Rose LF, Mealay BL, Genco RJ, Cohen DW editor. Periodontics: Medicine,Surgery, and Implants. China: Elsevier Mosby; 2004; 1050.

17. Sculean A, Nikolidakis D, Schwarz F. regeneration of periodontal tissues: combinations of barrier membranes and grafting materials-biological foundation and preclinical evidence: a systematic review. J Clin Periodontol. 2008; 35: 106. 
18. Zhang $Y, Z$ hang $X$, Shi B, Miron RJ. Membranes for guided tissue and bone regeneration. 2013; (Table 1): 1-10.

19. Bathla S. Regenerative Osseous Surgery. Periodontics Revisited. 2011. p. 371-4.

20. Needleman I, Worthington H, E G-L, Tucker R. Guided tissue regeneration for periodonta infra-bony defects. Cochrane Database Syst Rev. 2006; 29.

21. Shin S, Park H, Kim K, Lee M, Choi Y, Park $Y$. biological evaluation of chitosan nanofiber membrane for guided bone regeneration. J Periodontol. 2005; 76: 1778.

22. Rakhmatia Y, Ayukawa Y, Furuhashi A, Koyano K. Current barrier membranes: Titanium mesh and other membranes for guided bone regeneration in dental application. $\mathrm{J}$ Prosthodont Res. 2013; Jan: 57 (1): 3-14.

23. Jovanovic $S$, Nevins $M$. bone formation utilizing titanium-reinforced barrier membranes. Int $\mathrm{J}$ Periodontics Restorative Dent. 1995; 15: 56.

24. Behring J, Junker R, Walboomers X, Chessnut $\mathrm{B}$, Jansen $\mathrm{J}$. Toward guided tissue and bone regeneration: morphology, attachment, proliferation, and migration of cells cultured on collagen barrier membranes. a Syst Rev Odontol. 2008; 96: 1.

25. Millela D, Ramires P, Brescia E, La Sala G. Physiocochemical, mechanical and biologaical properties of commercial membranes for GTR. J Biomed Mater Reseaarch. 2001; 58: 427.

26. Li J, Zuo Y, Cheng X, Yang W, Wang H, Li $Y$. preparation and characterization of nanohydroxyapatite/polyamide 66 composite GBR membrane with asymmetric porous structure. J Mater Sci Mater Med. 2009; 20: 1031.

27. Thoma D, Halg G, Dard M, Seibl R, Hammerle $C$, Jung R. Evaluation of a new biodegradable membran to prpevent gingival ingrowth into mandibular bone defect in minipigs. Clin oral Implantol Res. 2009; Jan (20)(1): 7-16.

28. Felipe M, Andrade P, Grisi M, Souza S, Taba M, Palioto D. Comparison of two surgical procedur for use of the acellular dermal matrix graft in the treatment of gingival recession: a randomized controlled clinical study. J Periodontol. 2007; 78: 1209.

29. Bottino $M$, Jose $M$, Thomas $V$, Dean $D$, Janowski G. Acellular dermal matrix graft: synergistic effect of rehydration and natural crosslinking on mechanical properties. J Biomed Mater Res Part B Appl Biomater. 2010; 95: 276.

30. Gouk S, Lim T, Teoh S, Sun W. Alteration of hman acellular tissue matirx by gamma irradiation: histology biomechanical property, stability, in vitro cell repopulation and remodeling. J Biomed Mater Res Part B Appl Biomater. 2008; 84: 205.

31. Livesey S, Herndon D, Hollyoak M, Atkinson Y, Nag. A Transplanted acellular allograft dermal matrix-potential as a template for the reconstruction of viable dermis. Transplantation. 1995; 601.

32. Chen F, LA W, Zhang R, Sun H. Homing of endogenous stem/progenitor cells for in situ tissue regeneration: promises, stategies and translational prerspectives. Biomaterial. 2011; 32: 3189.

33. Srouji S, Ben-David D, Lotan R, Livne E, Avrahami R. Slow-release human recombinant bone morphogenic protein-2 embedded withing electrospun scaffolds for regeneration of bone defect: in vitro and in vivo evaluation. Tissue Eng Part A. 2011; 17: 269.

34. Bottino M, Thomas V, Janowski G. A novel spatially designed and functionally graded elecstropun membrane for periodontal regeneraion. Acta Biomater. 2011; 7: 216.

35. Li W, Laurencin C, Caterson E, Tuan R, Ko F. Electrospun nanofibrous structure: a novel scaffold for tissue engineering. J Biomed Mater Res. 2002; 60: 613.

36. Li, Cooper J, Mauck R, Tuan R. Fabrication and characterization of six electrospun poly(alphahydroxy ester)-based fibrous scaffolds for tissue engineering application. Acta Biomater. 2006; 2: 377. 
37. Thomas V, Zhang X, Cetledge S, Vohra Y. Functionally graded electrospun scaffolds with tunable mechanical properties for vascular tissue regeneration. Biomed Mater. 2007; 2: 224.

38. Al-Mubarak S, Karring TAH. Clinical evaluation of subgingival applicationn of metronidazole $25 \%$ and adjuctive therapy. J Int Acad Periondotology. 2000; 2: 64.

39. Karsenty G. The genetic transformation of bone biology. Gene Dev. 1999; 13: 3037.

40. El-Ghannam. A bone reconstruction from bioceramics to tissue engineering. Expert Rev Med Devices. 2005; 57: 87.

41. Chou A, LeGeros R, Chen Z, Li Y. Antibacterial effect of zinc phosphate mineralized guided bone regeneration membranes. Implant Dent. 2007; 16: 89.

42. Chen F, Zhang J, Zhang M, An Y, Chen F, Wu Z. A review of endogenous regenerative technology in perodontal regenerative medicine. Biomaterials. 2010; 31: 7892.
43. Rathe F, Junker R, Chesnutt B, Jansen J. The effect of enamel matrix derivative (Emdogain) on bone formation: a systematic review. Tissue engineering Part B:Reviews. 2009; 15: 215.

44. Thoma D, Villar C, Carnes D, Dard M, Chun Y, Cochran D. Angiogenic activity of an enamel matrix derivative (EMD) and EMD-derived protein: an experiment study in mice. $\mathrm{J}$ Clin Periodontol. 2011; 38: 253.

45. Granding H, Gemperli A, Dard M. Enamel matrid derivative: a review of cellular effect in vitro and a model of molecular arrangement and functioning. Tissue engineering Part $\mathrm{B}$ : 2011; December.

46. Fisher $\mathrm{O}$, Khademhosseini $\mathrm{A}$, Langer $\mathrm{R}$, Peppas N. Bioinspired material for controlling stem cell fate. Acc Chem Res. 2010; 43: 419.

47. Lin C, Anseth K. PEG hydrogels for the controlled release of biomolecules in regenerative medicine. Pharm Res. 2009; 26: 631. 